UDC 334.012.42:330.43

JEL Classification: C51, 012

http://doi.org/10.21272/mmi.2018.4-12

Tetiana Zatonatska,

D.Sc., Professor, Taras Shevchenko National University of Kyiv, Ukraine

Oleksandr Rozhko,

D.Sc., Professor, Taras Shevchenko National University of Kyiv, Ukraine

Nataliia Tkachenko,

D.Sc., Professor, Taras Shevchenko National University of Kyiv, Ukraine

\title{
Modern trends of impact on economic development of countries: e-commerce and R\&D
}

\begin{abstract}
The rapid development of information technology provides high growth rates of e-commerce. Today, e-business plays an important role in the structure of economies of advanced countries. In Ukraine, it develops more slowly than in neighbouring countries due to economic, social and political instability, low purchasing capacity of the population, lower demand for goods and services, devaluation of hryvnia, currency fluctuations, etc. However, domestic economists predict that the importance of e-commerce for the Ukrainian economy will increase annually. In such circumstances, the issue of identifying relationships between e-commerce and investment in research and development with the country's economic development becomes relevant as well as finding of tools for measuring the extent of e-commerce's impact on economic growth. The aim of the article is to construct a set of economic and mathematical models to assess the impact of e-commerce and investment in research and development on the country's economic development. Comparing the results of modelling in three countries, it has been determined that the value of e-commerce and R\&D expenditures is more significant for GDP per capita growth in Ukraine and Poland due to the higher level of ICT development in Austria and its approximation to the saturation point relative to the growth rates of innovation industries. While comparing the levels of exposure to e-commerce and R\&D costs in these countries, it was found that e-commerce occupies the first position only in Austria. While analysing the parameters of the models of three countries, it has been determined that GDP per capita is the most sensitive to changes in the indicators in the Ukrainian model. That demonstrates that the economy of Ukraine is less stable compared to Poland and Austria. Expenditure on R\&D and e-commerce has a significant impact on the country's economic development and contributes to increasing of gross domestic product and productivity of manufacture.
\end{abstract}

Keywords: e-commerce, research and development, economic development, economic growth, economic and mathematical modelling.

Introduction. The innovation of national economies is ensured by the proliferation and creation of modern ICTs and scientific results that turn into innovative products and services. Unfortunately, the reduction of financing of basic science in Ukraine, which is connected with the deficit of public finances, does not allow to compete with Ukrainian enterprises from TNCs. Nevertheless, the emergence of new types of economic activities, such as e-commerce and its related areas (cloud services, electronic payment systems, etc.) create conditions for activating private investment in innovative developments. In Ukraine, e-commerce as a type of e-business is at the formative stage and it is gaining greater importance in the context of globalization transformations. However, there are certain obstacles, first of all - the absence of world leaders in e-commerce in the Ukrainian digital market, gaps in national legislation, etc. The rapid development of information technology provides high growth rates of e-commerce. Today, e-business occupies an important sector in the economies of advanced countries. In Ukraine, it develops a bit more slowly than in neighbouring countries, due to economic, social and political instability, the low purchasing power of the population, lower demand for goods and services, devaluation of hryvnia, currency fluctuations, etc. Though, domestic economists predict that the importance of e-commerce for the

Cite as: Zatonatska, T., Rozhko, O., \& Tkachenko, N. (2018). Modern Trends of Impact on Economic Development of Countries: E-Commerce and R\&D. Marketing and Management of Innovations, 4, 129-135. http://doi.org/10.21272/mmi.2018.4-12 
Ukrainian economy will increase annually.

In such circumstances, the issue of identifying relationships between e-commerce and investment in research and development with the country's economic development becomes relevant, as well as finding tools for measuring the extent of e-commerce's impact on economic growth.

Analysis of recent research and publications. In recent years, many kinds of research have been devoted to the study of the relationship between ICT, economic growth and productivity growth. In papers written by R. Anvari, D. Norouzi [1], Tk. Liu, Jr. Chen, C. Huang, C. Yang [2], M. Lund, S. McGuire [3] the impact of e-commerce and R\&D on economic development and productivity is proved. $\mathrm{E}$. Karlsson, J. Liljevern [4], A. Yousefi [5], T. Niebel [6], F. Venturini [7] in their papers came to the conclusion that there is a positive relationship between the use of the Internet, ICT and increased productivity. In addition, research findings, which were covered in the papers of Z. Hossain, M. Ishaq Bhatti, Z. Ali [8], T. Pham, D. Nguyen [9], at the firm level show that ICTs can help increase the efficiency of enterprise management. In the papers [10-11], in analysing and modelling the impact of e-commerce parameters on economic development indicators, the Cobb-Douglas production function was used as an effective tool for determining the relationships between e-commerce and economic growth.

Unsettled issues which are part of a common problem. Continuing the scientific discussion on increasing the rates of economic development of the countries in the conditions of the public finances deficit, it is necessary to justify state support to certain sectors of the economy and identify types of economic activity that have a significant impact on economic growth.

The aim of the article. The aim of the article is to construct a set of economic and mathematical models to assess the impact of e-commerce and investment in research and development on the country's economic development.

The main material. The development of information technology and the spread of e-commerce lead to increased business management efficiency, more productive asset utilization, faster market entry, reduced overall order execution time and increased customer service delivery.

Today, there are a number of works [2-3], focusing on the contribution of e-commerce to the economic growth of countries, and it has been proved that e-commerce has increased corporate profits and contributed to the development of countries. The results of the research showed that e-commerce is a key factor in integrating low-growth countries into the world trading system. The focus of these papers is on how social and economic reforms can stimulate e-commerce. It is proved that almost no influence of the authorities in the area of electronic commerce can lead to economic growth and increase the share of ecommerce in the overall structure of the economy. The carried-out research in the work [2], which focuses on the study of the impact of e-commerce and R\&D investment on production performance, draws attention to the use of the unique set of panel data, obtained from Taiwanese firms from 1999 to 2002. It has been found that e-commerce and capital invested in R\&D have positively affected productivity.

Based on the model presented in the work [2], the author constructed a model for studying the impact of e-commerce and investment in research and development on indicators of economic development in Ukraine, as well as detailed analysis of it. The results of the modelling of the relationships between ecommerce, R\&D and economic growth in Ukraine were comparable to the results of similar modelling in Poland and Austria.

Let's consider more detailed models. In this study, the technique of panel modelling is used. To construct models, the following equation was used:

$$
G D P P_{i t}=\alpha+\beta_{1} E C_{i t}+\beta_{2} R \& D_{i t}+\beta_{3} G S_{i t}+H E_{i t}+e_{i t}
$$

where $\alpha$-constant (free variable); $\beta_{1}, \beta_{2}, \beta_{3}$,- model parameters; $t$ - number of time period; $i$-country number (in the research the name of the chosen country which are used as the index: 
ukr - Ukraine, pol - Poland, aut - Austria); GDPP - GDP per capita, based on purchasing power parity, measured in thousands of US dollars; $E C$ - Internet sales volume in thousands of US dollars; $R \& D$ - expenditures on R\&D, thousands of US dollars; GS - the size of power, based on the final consumption expenditure in the public sector, thousands of US dollars; $H E$ - health care expenditures in thousands of USA dollars.

Since all independent variable models have the same measurement units, the corresponding parameters do not require any transformation.

Annual data was selected for the period from 1990 to 2017 for modelling. Data is taken from the official sites of Eurostat [12], World Bank [13], the State Statistics Service of Ukraine [14] and the Ministry of Finance of Ukraine [15]. All calculations and analysis are done in Microsoft Excel and R Studio.

The model, which was built using data for Ukraine, in mathematical interpretation has the following form (2):

$$
\begin{gathered}
G D P P_{u k r}=2.923+5.36 \cdot 10^{-7} E C_{u k r}+3.17 \cdot 10^{-6} R \& D_{u k r}-1.64 \cdot 10^{-7} G S_{u k r}+ \\
+4.88 \cdot 10^{-7} H E_{u k r}
\end{gathered}
$$

According to the model, the following conclusions can be drawn. The coefficient for a variable of Internet sales is $5.36 \cdot 10^{-7}$, which means that with an increase in online sales in Ukraine per unit, GDP per capita will grow by $5.36 \cdot 10^{-7}$ thousand dollars. Positive per capita GDP is also affected by research and development and healthcare costs. With the growth of these indicators per unit, the gross domestic product

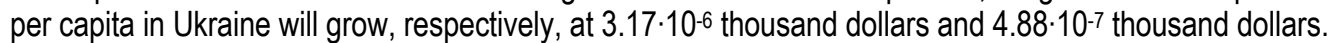
The negative impact on GDP was shown by the parameter of final consumption expenditure in the public sector: with the growth of this indicator per unit, GDP per capita will decrease by 1.64:10-7.

Let's consider the main characteristics of the model and carry out a detailed analysis. Table 1 shows the main parameters of the model for Ukraine.

Table 1 - The main parameters of the model for Ukraine

\begin{tabular}{|l|l|c|c|c|}
\hline Country & Variables & Coefficients value & p-value & Residual error \\
\hline Ukraine & GDPP & 2,922788375 & $2,99314 \mathrm{E}-05$ & 0,564318 \\
\cline { 2 - 5 } & $E C$ & $5,36164 \mathrm{E}-07$ & 0,00028 & $1,25399 \mathrm{E}-07$ \\
\cline { 2 - 5 } & $R \& D$ & $3,17097 \mathrm{E}-06$ & 0,00271 & $1,34366 \mathrm{E}-06$ \\
\cline { 2 - 5 } & $G S$ & $-1,63603 \mathrm{E}-07$ & 0,02827 & $1,48736 \mathrm{E}-07$ \\
\cline { 2 - 5 } & $H E$ & $4,88322 \mathrm{E}-07$ & 0,02128 & $3,81079 \mathrm{E}-07$ \\
\cline { 2 - 5 } & F-statistic & 41,47762 & & \\
\cline { 2 - 5 } & R-squared & 0,87825 & & \\
\hline
\end{tabular}

Sources: compiled by the author based on modelling results

As seen from Table 1 all coefficients for variables are crucial with a significance level of 0.95 . The $R$ squared in the model for Ukraine is high (0.878), indicating a significant relationship between dependent and independent variables. If we analyze the correlation coefficient between the parameters $r=0,937>0,9$, we can conclude that there is a considerable relationship between them.

The results of the unit root test for the Ukrainian model showed that all variables are stationary with the first difference, that is, a zero hypothesis with a $1 \%$ significance level was rejected. This indicates the presence of a unit root.

The results of the Pedroni cointegration test for the model indicate that most of the statistical data in 

and R\&D

the GDP model rejected the null hypothesis of the lack of cointegration. This indicates that all independent variables, such as e-commerce, $R \& D$, government size and health care expenditures, had long-term relationships with GDP per capita based on purchasing power parity.

During the analysis of the model for Ukraine, tests for the presence of multicollinearity, autocorrelation and heteroscedasticity are also conducted. The assumption of multicollinearity was rejected using the VIF criterion. The Breush-Godfrey test made it possible to conclude that there is no autocorrelation. However, in this model, there is heteroscedasticity, which confirmed by the White test.

In addition, a Dickey-Fuller Augmented Test (ADF - test) was conducted for stationarity. The low value of $p$-value indicates the stationarity of the time series.

In general, it can be said that in Ukraine, according to the results of modelling, economic growth depends to large extent on the cost of R\&D. However, e-commerce is ranked second in terms of per capita GDP, which is also important for the country's economic development. These conclusions are logical, as the basis for the development of e-commerce is the high rate of dissemination of innovative technologies, including the Internet, broadband Internet access, cloud technologies, electronic payment systems, etc. Compared to Poland and Austria, Ukraine lags behind the indicator of ICT development, as well as the volume of trade through the Internet and the degree of penetration of the Internet.

The following model was built using data for Poland. The same time period and the same information sources as for the Ukrainian model have been considered in the research. The mathematical model equation for Poland is as follows (3):

$$
\begin{aligned}
G D P P_{p o l}= & 5.772+1.51 \cdot 10^{-7} E C_{p o l}+1.89 \cdot 10^{-6} R \& D_{p o l}- \\
& -5.44 \cdot 10^{-8} G S_{p o l}+3.54 \cdot 10^{-7} H E_{p o l}
\end{aligned}
$$

As can be seen from equation 2 , the intercept of the model is 5,772 . That is, in the absence of the influence of independent variables, the level of GDP per capita on the basis of the purchasing power parity will amount to 5,772 thousand dollars. Changing Internet sales will have the following effect on GDP: with the growth of this indicator per unit, the gross domestic product per capita will increase by $1.51 \cdot 10^{-7}$ thousand dollars. The positive impact will also be on research and development costs - an increase of one

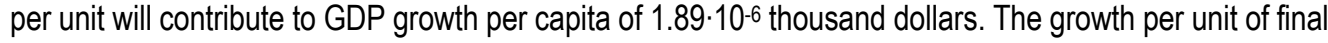
consumption expenditure in the public sector as in the Ukrainian model shows a negative impact on GDP in the form of a decrease of $5.44 \cdot 10^{-8}$ thousand dollars. The indicator of health care expenditures increased by one will increase GDP per capita by $3.54 \cdot 10^{-7}$ thousand dollars.

As in the previous model, its main parameters were analyzed, as well as tests for the presence of multicollinearity, heteroscedasticity and autocorrelation were performed. The main parameters can be seen in table 2

Table 2 - The main parameters of the model for Poland

\begin{tabular}{|c|l|c|c|c|}
\hline Ukraine & Variables & Coefficients value & p-value & Residual error \\
\hline Poland & $G D P P$ & 5,772278 & $2,76922 \mathrm{E}-08$ & 0,703479 \\
\cline { 2 - 5 } & $E C$ & $1,5088 \mathrm{E}-07$ & 0,02833 & $6,44814 \mathrm{E}-08$ \\
\cline { 2 - 5 } & $R \& D$ & $1,89702 \mathrm{E}-06$ & 0,03784 & $8,60912 \mathrm{E}-07$ \\
\cline { 2 - 5 } & $G S$ & $-5,44007 \mathrm{E}-08$ & 0,05842 & $9,80275 \mathrm{E}-08$ \\
\cline { 2 - 5 } & $H E$ & $3,53609 \mathrm{E}-07$ & 0,01382 & $2,30236 \mathrm{E}-07$ \\
\cline { 2 - 5 } & F-statistic & 30,64948 & \multicolumn{2}{|c}{} \\
\cline { 2 - 5 } & R-squared & 0,97158 & & \\
\hline
\end{tabular}

Sources: compiled by the author based on modelling results 
Thus, by analysing the model's parameters, we can say that the high determination coefficient $\mathrm{R}^{2}=$ 0.972 indicates a strong correlation between the variables. All variables are crucial at a significance level of $91 \%$.

For the Polish model, a single root test was also conducted, the results of which rejected the null hypothesis and confirmed the presence of a single root. The results of the Pedroni test indicate that there are long-term relationships between the model parameters.

Using White's test, it was found that there is heteroscedasticity in the model for Poland. The BreushGodfrey test confirmed the lack of autocorrelation. Using the VIF criterion for the Polish model, we obtained results indicating that there is no multicollinearity in it.

Summarizing, it should be noted that this model shows the impact of Internet sales, R\&D expenditures, final consumption expenditure in the public sector, and health expenditure on Poland's economic growth. From the simulation results, it can be concluded that, as in the Ukrainian model, R\&D spending is more important for GDP per capita growth compared to online sales. The least impact on the GDP of the Polish model has the final consumption expenditure in the public sector.

We will analyze the latest model of the relationship between e-commerce and spending on R\&D and GDP per capita on the basis of the purchasing power parity of Austria.

The model for Austria in mathematical terms has the following form (4):

$$
\begin{gathered}
G D P P_{a u t}=4.58+1.55 \cdot 10^{-7} E C_{a u t}+6.66 \cdot 10^{-8} R \& D_{a u t}-4.80 \cdot 10^{-8} G S_{a u t}+ \\
+1.17 \cdot 10^{-6} H E_{\text {aut }}
\end{gathered}
$$

Consequently, the coefficients of the variables responsible for Internet sales and $R \& D$ costs are respectively $155 \cdot 10^{-7}$ and $6.66 \cdot 10^{-8}$. This means that with the increase of data on the unit, GDP per capita will grow, respectively, at $1.55 \cdot 10^{-7}$ and $6.66 \cdot 10^{-8}$ thousand dollars. The growth of final consumption expenditure in the public sector will affect the decline of the Austrian economic growth rate by $4.8 \cdot 10^{-8}$ thousand dollars and health care costs, on the contrary, will contribute to economic growth of $1.17 \cdot 10^{-6}$ thousand dollars.

The analysis of the main parameters of the model (Table 3) showed that all variables are significant with a significance level of $91 \%$. The relationship between the model's indicators is significant, which confirms the high values of $R$-squared and correlation coefficients $\left(R^{2}=0.975 ; r=0.988\right)$.

Table 3 - The main parameters of the model for Austria

\begin{tabular}{|c|l|c|c|c|}
\hline Country & Variables & Coefficients value & p-value & Residual error \\
\hline \multirow{4}{*}{ Austria } & $G D P P$ & 4,58300 & 0,00723 & 1,555047726 \\
\cline { 2 - 5 } & $E C$ & $1,55 \mathrm{E}-07$ & 0,01032 & $5,53104 \mathrm{E}-08$ \\
\cline { 2 - 5 } & $R \& D$ & $6,66 \mathrm{E}-07$ & 0,26603 & $5,84273 \mathrm{E}-07$ \\
\cline { 2 - 5 } & $G S$ & $-4,80 \mathrm{E}-08$ & 0,00900 & $4,61702 \mathrm{E}-08$ \\
\cline { 2 - 5 } & $H E$ & $1,17245 \mathrm{E}-06$ & $0,06583 \mathrm{E}-07$ & $1,73104 \mathrm{E}-07$ \\
\cline { 2 - 5 } & F-statistic & 12,12363 & & \\
\cline { 2 - 5 } & R-squared & 0,97527 & & \\
\hline
\end{tabular}

Source: compiled by the author based on simulation results

The results of the unit root test for the Austrian model showed that all variables are stationary in the first differences, that is, a zero hypothesis with a $1 \%$ significance level was rejected indicating the presence of a unit root.

The Pedroni test for the model of Austria rejected the null hypothesis of lack of cointegration. This indicates that all independent variables had a long-term relationship with GDP per capita based on 
purchasing power parity.

For the model built on the data of Austria, tests for the presence of multicollinearity, autocorrelation and heteroscedasticity are also conducted. The assumption of multicollinearity was rejected using the VIF criterion. The Breush-Godfrey test made it possible to conclude that there is no autocorrelation. There is also no heteroscedasticity, which confirmed by the White test.

In addition, a Dickey-Fuller Augmented Test (ADF - test) was tested for stationarity. The low value of p-value indicates the stationarity of the time series.

Thus, it can be said that the model of Austria differs from the models for Ukraine and Poland by the fact that for this country, e-commerce is more important in terms of economic development than the cost of research and development. It should also be noted that while comparing the coefficients for all model parameters, it has been found that the highest impact on GDP per capita in Austria has been spent on health care, which was not observed in the two previous models.

Conclusions and further research. Comparing the results of modelling in three countries, it has been determined that the value of e-commerce and R\&D expenditures is more significant for GDP per capita growth in Ukraine and Poland, due to the higher level of ICT development in Austria and its approximation to the saturation point relative to the growth rates of innovation industries. While comparing the levels of exposure to e-commerce and R\&D costs in these countries, it is found that e-commerce occupies the first position only in Austria.

While analysing the parameters of the models of the three countries, it is determined that GDP per capita is the most sensitive to changes to indicators in the Ukrainian model. It demonstrates that Ukraine's economy is less stable compared to Poland and Austria.

Expenditures on R\&D and e-commerce has a significant impact on the country's economic development and contributes to increasing the volume of the gross domestic product and productivity of manufacture, which will further enhance the research in this direction.

\section{References}

1. Anvari, R. \& Norouzi, D. (2018), "The impact of e-commerce and R\&D on economic development in some selected countries", available at https://fardapaper.ir/mohavaha/uploads/2018/01/Fardapaper-The-Impact-of-E-commerce-and-RD-onEconomic-Development-in-Some-SelectedCountries.pdf (Accessed 25 October 2018).

2. Liu, Tk., Chen, Jr., Huang, C. J. \& Yang, Chi. (2013). E-commerce, R\&D, and productivity: Firm-level evidence from Taiwan. Information Economics and Policy, 25, 272-283.

3. Lund M., J. F., \& McGuire, S. (2005). Institutions and development: Electronic commerce and economic growth. Organization Studies, 26(12),1743-1763.

4. Karlsson, E. \& Liljevern, J. (2017). ICT Investment and the Effect on Economic Growth: International business school "Jönköping university», Bachelor thesis.

5. Yousefi, A. (2011). The impact of information and communication technology on economic growth: evidence from developed and developing countries. Economics of Innovation and New Technology, 20:6, 581-596.

6. Niebel, T. (2016). ICT and economic growth: Comparing developing, emerging and developed countries. ZEW Discussion Papers, 14, 117.

7. Venturini, F. (2006). ICT and Productivity Resurgence: A growth model for the Information Age. IDEAS Working Paper Series from RePEC, 259.

8. Hossain, Z., Ishaq Bhatti, M. \& Ali, Z. (2004). An econometric analysis of some major manufacturing industries: A case study. Managerial Auditing Journal, 19: 6, 790-795.

9. Pham, T. \& Nguyen, D. (2010). Does exchange rate policy matter for economic growth? Vietnam evidence from a cointegration approach. Economics Bulletin, 1, 169-181.

10. Zatonatska, T. \& Novosolova, V. (2017). Modeljuvannja vplyvu elektronnoji komerciji na ekonomičnyj rozvytok krajiny. [Modeling of impact of e-commerce on economic development]. Finansovo-kredytna dijal'nist : problemy teoriji ta praktyky-Financial and credit activity: problems of theory and practice, 1(22), 265-273. 


\section{T. Zatonatska, O. Rozhko, N. Tkachenko. Modern Trends of Impact on Economic Development of Countries E-commerce}

and R\&D

11. Zatonatska, T. (2018). Models for analysis of impact of the e-commerce on indicators of economic development of Ukraine, Poland and Austria. Marketing and Management of Innovations, 2, 44-53. http://doi.org/10.21272/mmi.2018.2-04

12. The official site of Eurostat. (2018), available at: https://ec.europa.eu/eurostat/data/database (Accessed 25 October 2018).

13. The official site of World Bank (2018), available at: https://data.worldbank.org/ (Accessed 25 October 2018).

14. The official site of State Statistics Service of Ukraine (2018), available at: http://www.ukrstat.gov.ua/ (The official site of Ministry of Finance of Ukraine (2018), available at: https://www.minfin.gov.ual (Accessed 25 October 2018).

T. Г. Затонацька, д.е.н., професор, Київський національний університет імені Тараса Шевченка (Україна);

О. Д. Рожко, д.е.н., професор, Київський національний університет імені Тараса Шевченка (Україна);

Н. В. Ткаченко, д.е.н., професор, Київський національний університет імені Тараса Шевченка (Україна).

Сучасні тренди впливу на економічний розвиток країн: електронна комерція та дослідження і розробки

Стрімкий розвиток інформаційних технологій забезпечуе високі темпи зростання обсягів електронної комерції. Визначено, що в Україні електронний бізнес розвивається трохи повільніше, ніж у сусідніх країнах, що зумовлено економічною, соціальною та політичною нестабільністю, низькою купівельною спроможністю населення, зниженням попиту на товари і послуги, девальвацією гривні, валютними коливаннями тощо. У статті актуалізується питання виявлення залежностей між електронною комерцією та інвестиціями у дослідження та розробки з економічним розвитком країни, а також пошуку інструментів виміру ступеня впливу електронної комерції на економічне зростання. Метою статтіє побудова комплексу економіко-математичних моделей для оцінки впливу електронної комерції та інвестицій у дослідження та розробки на економічний розвиток країн. Порівнююи результати моделювання за трьома країнами, визначено, що значення електронної комерції та витрат на дослідження та розробки є більш вагомим для зростання ВВП на душу населення в Україні та Польщі, що пояснюється більш високим рівнем розвитку інформаційних технологій в Австрії та ії наближення до точки насичення відносно показників зростання інноваційних галузей. При порівнянні ступенів впливу параметрів електронноі комерції та витрат на дослідження та розробки в зазначених країнах авторами, було виявлено, що лише в Австрії електронна комерція займає першу позицію. При аналіз параметрів моделей трьох країн, визначено, що ВВП на душу населення $\epsilon$ найбільш чутливим до зміни показників саме в українській моделі. Що свідчить про те, що економіка України є менш стійкою у порівнянні з Польщею та Австрією. У рамках дослідження, доведено, що витрати на дослідження та розробки та електронної комерції має суттєвий плив на економічний розвиток країн та сприяє підвищенню обсягу внутрішнього валового продукту й продуктивності виробництва.

Ключові слова: електронна комерція, дослідження та розробки, економічний розвиток, економічне зростання, економікоматематичне моделювання.

Manuscript received: 23.09.2018

(c) The author(s) 2018. This article is published with open access at Sumy State University. 